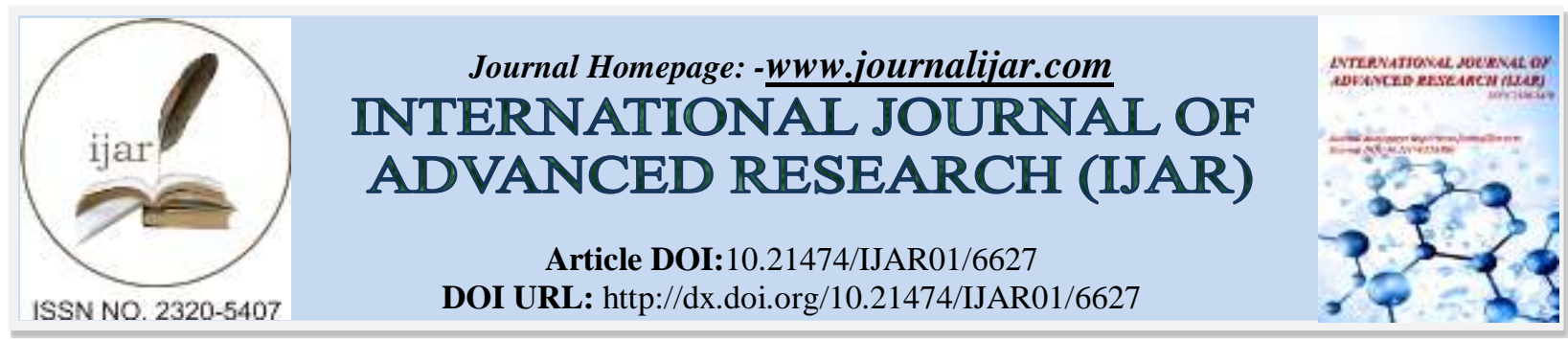

RESEARCH ARTICLE

\title{
AUTOPHAGY BIOMARKERS SQSTM1/P62 AND BECLIN-1 EXPRESSION IN BREAST CARCINOMA AND THEIR CLINICOPATHOLOGICAL SIGNIFICANCE.
}

Dina A. Khairy and Abla S. Mahmoud.

Department of Pathology, Faculty of Medicine, Beni-Suef University, Egypt.

\section{Manuscript Info}

Manuscript History

Received: 24 December 2017

Final Accepted: 26 January 2018

Published: February 2018

Keywords:-

Breast carcinoma, Autophagy,

SQSTM1/p62, Beclin-1,

immunohistochemistry

\section{Abstract}

Background: Clarifying the different mechanisms of molecular carcinogenesis of breast carcinoma could enable its better management, improving its prognosis and decreasing patient's mortality. Autophagy is the process of lysosomal degradation which could remove the damaged components so as to preserve cells homeostasis. Autophagy had a complicated role in cancer as it might inhibit or stimulate cancer progression which depend on the type of cancer. Several proteins which control autophagy had been discovered in human cells such as Beclin1and SQSTM1/p62 (Sequestosome-1) that played important roles in autophagy.

Aim of the work: This study aimed to assess expressions of autophagy markers SQSTM1/p62 and Beclin-1 in breast carcinoma comparing expression of both markers with clinicopathological parameters of that type of cancer.

Patients and methods: SQSTM1/p62, Beclin-1 expression was evaluated using immunohistochemistry on sixty paraffin blocks of breast carcinoma. Then correlations between their expression levels and clinicopathological parameters were done.

Results: SQSTM1-p62 overexpression in breast carcinoma was strongly related to higher grade $(=0.002)$ and American Joint Committee on Cancer staging system (AJCC stage) of the tumor, aggressive molecular type $(=0.009)$, presence of lymph node metastases $(=0.041)$, high KI67 index $(\mathrm{p}<0.001)$, negative ER\& PR hormonal receptors $(=0.01)$, Her2 neu expression $(=0.03)$, presence of distant metastasis $(\mathrm{p}=0.011)$. The sensitivity of $\mathrm{p} 62$ over-expression as a predictor for advanced stage of breast carcinoma was 72.4 and the specificity was 97.9. Beclin-1 low expression was significantly correlated with aggressive molecular type $(=0.004)$, higher grade $(\mathrm{p}<0.001)$ and AJCC stage of the tumor $(\mathrm{p}=0.002)$, presence of lymph node metastases $(=0.041)$, high KI67 index $(\mathrm{p}<0.001)$, negative ER\& PR hormonal receptors $(=0.003)$, high Her2 neu expression $(=0.006)$, presence of distant metastasis $(\mathrm{p}=0.011)$. But it had no significant correlation with histopathological subtype of breast cancer. The sensitivity of low Beclin-1 expression as a predictor 
For advanced stage of breast carcinoma was 85.5 and the specificity was 97.9. We found an inverse relationship between p62 and Beclin-1 (Spearman's $r=-0.806$ ),

Conclusion: SQSTM1-p62 over expression is a marker of poor prognosis, but Beclin-1 overexpression was a marker of good prognosis in breast carcinoma.

Copy Right, IJAR, 2018,. All rights reserved.

\section{Introduction:-}

Breast carcinoma is the commonest malignancy and the $2^{\text {nd }}$ cause of cancer related mortality in females all over the world (Siegel et al., 2014). It is the commonest among Egyptian female's cancers forming 34.26\% of females' malignant tumors (Mokhtar et al., 2007). Clarifying the different mechanisms of molecular carcinogenesis of breast carcinoma could enable its better management improving its prognosis and decreasing patient's mortality (Jemal et al., 2010). Autophagy is the process of lysosomal degradation which could remove the damaged components so as to preserve cells homeostasis (Young et al., 2009). Autophagy had a complicated role in cancer as it might inhibit or a stimulate cancer progression which depend on the type of cancer (Mathew and White, 2011). Autophagy could allow cancer cells to resist stressful conditions like radiotherapy and chemotherapy, or it could inhibit cancer growth by removing oncogenic components and destroyed organelles (White, 2012). Several proteins which control autophagy had been discovered in human cells (Weidberg et al., 2011), e.g. Beclin-1 (Cao and Klionsky, 2007), (Kondo et al., 2005) and SQSTM1/p62 (Sequestosome-1) (Lamark et al., 2009), that played important roles in autophagy in normal and malignant cells. Many previous studies assessed their expression in cancer but the results are still conflicting.

Aim of the work this study aimed to assess expressions of autophagy markers SQSTM1/p62 and Beclin-1 in breast carcinoma comparing expression of both markers with clinicopathological parameters of that type of cancer.

\section{Patients and methods:-}

We have included sixty formalin fixed paraffin-embedded blocks of breast carcinoma of different histological subtypes were collected from the Pathology Department, Faculty of Medicine, Beni-Suef University and Pathology Department, Kasr Al Aini Hospital.. We used the American Joint Committee on Cancer staging system (AJCC) classification $7^{\text {th }}$ edition carcinoma staging (Edge and Compton, 2010) and Nottingham (Elston-Ellis) modified Scarff- Bloom-Richardson grading system for carcinoma grading (Elston, 2002). We detected age of the patient, cancer size, histolopathological subtype, grade, stage, lymph node, and distant metastasis by examination of the patient's and the slide files in Pathology Department.

\section{Immunohistochemical staining:-}

Immunohistochemical analysis was done by using the streptavidin-biotin immunoperoxidase method (Hsu et al., 1981), then we had incubated slides with monoclonal. Anti-SQSTM1-p62 antibody [ab56416] (Abcam-CambridgeMassachusetts- USA) diluted 1: 200 and primary rabbit polyclonal Anti-Beclin-1 ab ab55878 (Abcam) was diluted 1: 50 in blocking solution. We used tonsils and rat brain sections as a positive control for SQSTM1-p62 and for Beclin-1respectively.

Evaluation of immunohistochemical expressions of both Beclin-1 and SQSTM1/p62 proteins:-

We have evaluated both extent and the intensity of stain for both markers. The extent had been graded as zero (negative), one ( $<30 \%$ positive) and two ( $>30 \%$ positive) and we have graded the intensity was as zero (negative), one (weak), two (moderate) and three (strong). Then we have multiplied both scores to have a total final score: negative (from zero to one), low (from two to four) and high (five and six) (Won et al., 2009), score less than four was considered as low expression and scores more than four as high expression.

\section{Statistical analysis:-}

Continuous variables were expressed as the mean \pm SD and median (range) and the categorical variables were expressed as a number (\%).A P value less than 0.05 was considered statistically significant. Percent of categorical variables were compared using Pearson's w2-test or Fisher's exact test when appropriate. The strength of the relationship between SQSTM1-p62, Beclin-1 and clinicopathological features was determined by computing Spearman's correlation coefficient. 


\section{Results:-}

Sixty females' patients were included in our study, with age ranged from 39-77 years (Mean \pm SD: 56.35 \pm 10.99 ). Demographic data of all patients were detailed in table (1).

SQSTM1/p62 expression in relation to clinicopathological features:-

SQSTM1/p62 overexpression in breast carcinoma was significantly correlated with older age of the patients, higher grade $(=0.002)$ and AJCC stage of the tumor, aggressive molecular type $(=0.009)$, presence of lymph node metastases $(=0.041)$, high KI67 index $(\mathrm{p}<0.001)$, negative ER\& PR hormonal receptors $(=0.01)$, high Her2 neu expression $(=0.03)$, and presence of distant metastasis $(\mathrm{p}=0.011)$. But it had no significant correlation with histopathological subtype of breast cancer. Tables 2\& 4; fig 1

The sensitivity of high p62 expression as a predictor for advanced stage of infiltrating duct carcinoma (IDC) was 72.4 and the specificity was 97.9

\section{Beclin-1 immunoexpression and its correlation with clinicopathological features:-}

Beclin-1 was cytoplasmic and its low expression was significantly correlated with older age of the patients, aggressive molecular type $(=0.004)$, higher grade $(\mathrm{p}<0.001)$ and AJCC stage of the tumor $(\mathrm{p}=0.002)$, presence of lymph node metastases $(=0.041)$, high KI67 index $(p<0.001)$, negative ER\& PR hormonal receptors $(=0.003)$, high Her2 neu expression $(=0.006)$, presence of distant metastasis $(\mathrm{p}=0.011)$. But it had no significant correlation with histopathological subtype of breast cancer. Tables 3\& 4; fig 2

The sensitivity of low Beclin-1 expression as a predictor for advanced stage of IDC was 85.5 and the specificity was 97.9 Table 5

Correlation between immunohistochemical expression of SQSTM1/P62, Beclin-1, in IDC:-

We found an inverse relationship between SQSTM1/P62 and Beclin-1 expression (Spearman's r $=-0.806$ ). Table 4

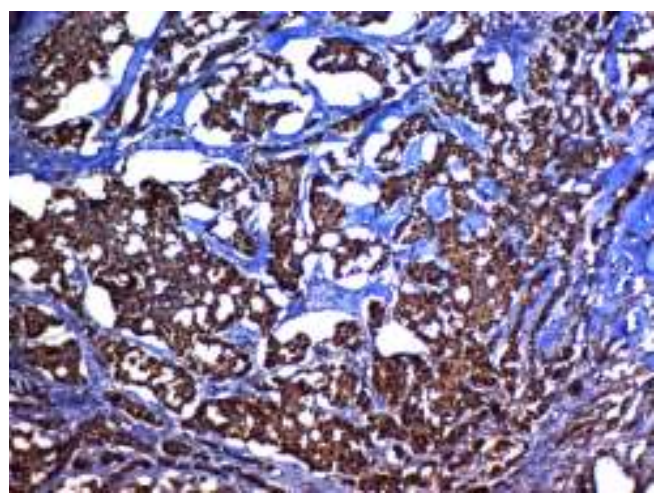

Fig 1 A

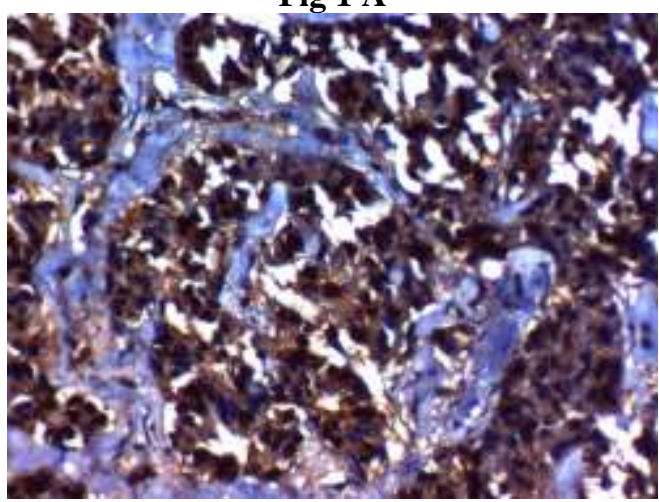

Fig 1 B 


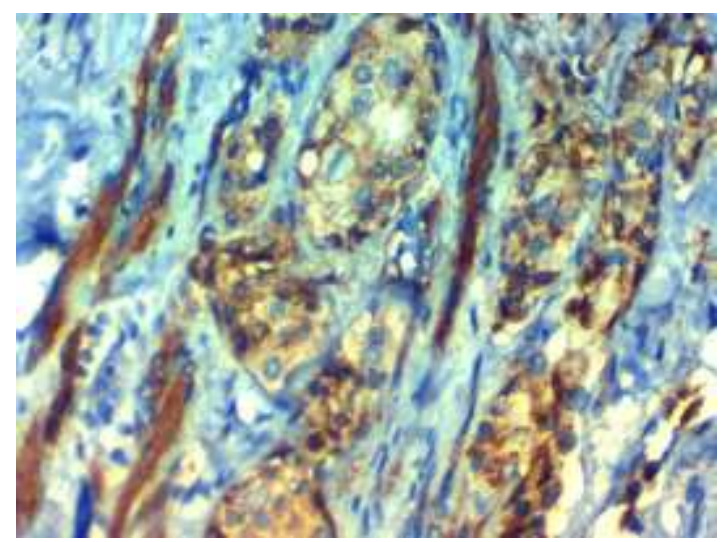

Fig 1 C

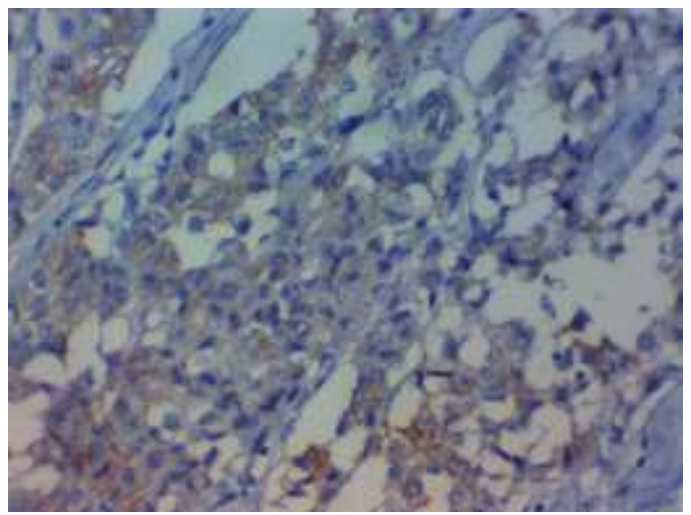

Fig 1 D

Figure 1:- Immunohistochemical staining carcinoma of SQSTM1/p62 expression in carcinoma of the breast: (A) High expression in the cytoplasm of high grade infiltrating duct carcinoma of the breast stage IV $x 400$. (B) High expression in the cytoplasm of high grade infiltrating duct carcinoma stage III x400 (C) Low expression in the cytoplasm of low grade infiltrating duct carcinoma of the breast stage IIx400 (D) Low expression in the cytoplasm of low grade infiltrating duct carcinoma stage I x400.

Note: high SQSTM1/p62 immunohistochemical expression (in the cytoplasm) in high grade and stage IDC

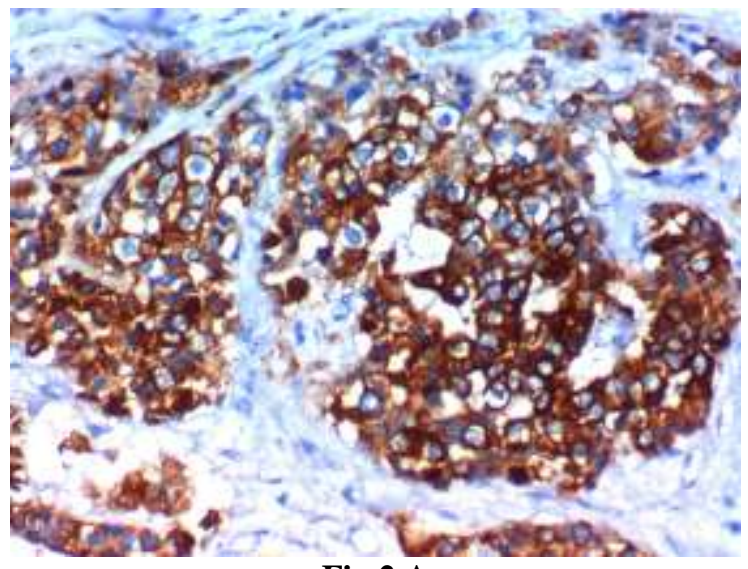

Fig 2 A 


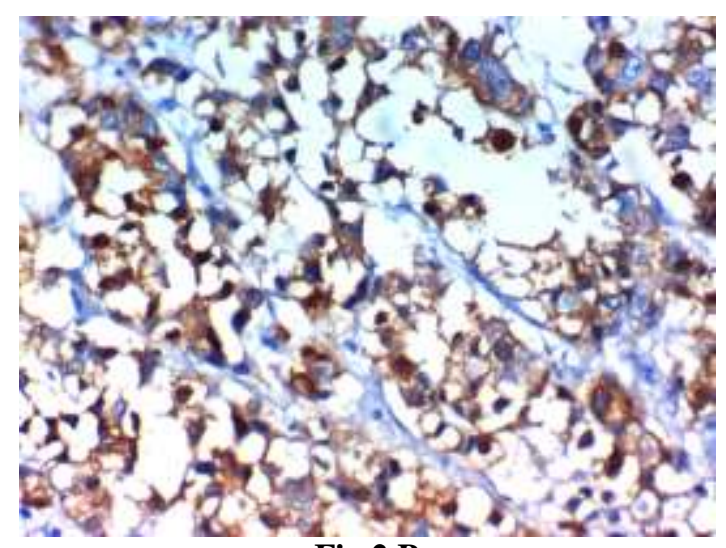

Fig 2 B

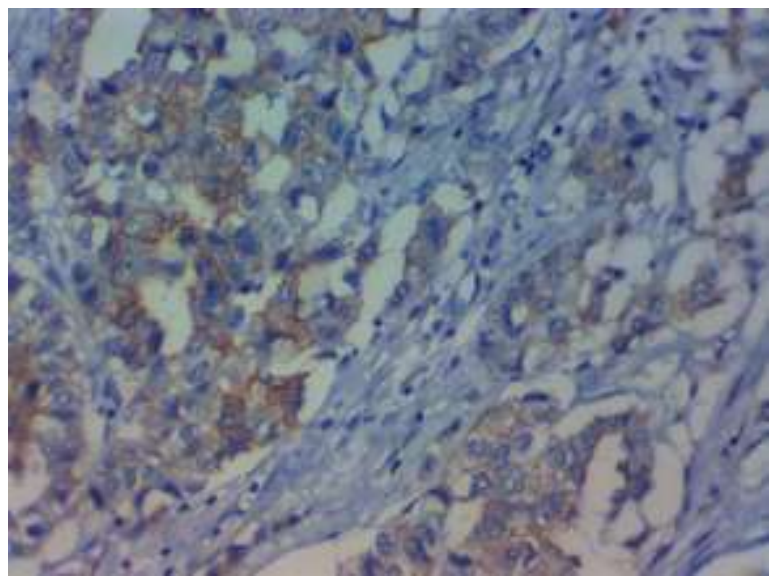

Fig 2 C

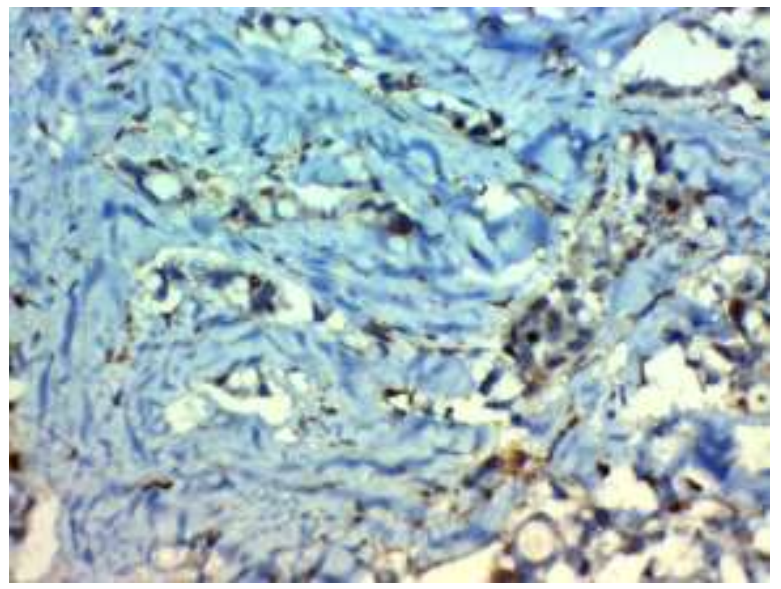

Fig 2 D

Figure 2:- Immunohistochemical staining carcinoma of Beclin-1 expression in carcinoma of the breast the breast: (A) High expression cytoplasm of low grade infiltrating duct carcinoma breast stage I x400. (B) High expression of low grade infiltrating duct carcinoma stage II x400 (C) Low expression in the cytoplasm infiltrating duct carcinoma of the breast $\mathrm{x} 400$ expression in the cytoplasm of high grade infiltrating duct carcinoma of the breast stage IIIx 400 .

(D) Low expression in the cytoplasm infiltrating duct carcinoma of the breast $x 400$ expression in the cytoplasm of high grade infiltrating duct carcinoma of the breast stage IVx400

Note:- low beclin-1 immunohistochemical expression (in the cytoplasm) in high grade and stage IDC 
Table 1:- Clinicopathological features and immunohistochemical staining in our patients

\begin{tabular}{|c|c|c|c|c|c|}
\hline Characteristics & Number & Percent & Characteristics & Number & Percent \\
\hline Age (years) & & & $\underline{T}$ & & \\
\hline Mean \pm SD & 56.35 & \pm 10.99 & $\mathrm{~T} 1$ & 13 & $21.7 \%$ \\
\hline Median Range & 57 & $(39-77)$ & $\mathrm{T} 2$ & 11 & $18.3 \%$ \\
\hline $\begin{array}{l}\leq 55 \text { years } \\
\geq 55 \text { years }\end{array}$ & $\begin{array}{l}24 \\
36\end{array}$ & $\begin{array}{l}40 \% \\
60 \%\end{array}$ & T3 & 22 & $36 \%$ \\
\hline $\begin{array}{l}\text { Size } \\
\text { Mean } \pm \text { SD } \\
\text { Median (Range) } \\
\leq 5 \mathrm{~cm} \\
\geq 5 \mathrm{~cm}\end{array}$ & $\begin{array}{l}6.33 \pm 3.59 \\
7(1-13) \\
24 \\
36\end{array}$ & $\begin{array}{l}40 \% \\
60 \%\end{array}$ & $\mathrm{~T} 4$ & 14 & $23.3 \%$ \\
\hline Pathological type & & & Lymph node & & \\
\hline IDC & 49 & $81.7 \%$ & Negative & 19 & $31.7 \%$ \\
\hline Other & 11 & $18.3 \%$ & Positive & 41 & $68.3 \%$ \\
\hline Grade & & & $\mathrm{N}$ & & \\
\hline Grade I & 10 & $16.7 \%$ & N0 & 19 & $31.7 \%$ \\
\hline Grade II & 15 & $25 \%$ & N1 & 7 & $11.7 \%$ \\
\hline \multirow[t]{2}{*}{ Grade III } & 35 & $58.3 \%$ & $\mathrm{~N} 2$ & 21 & $35 \%$ \\
\hline & & & N3 & 13 & $21.7 \%$ \\
\hline ER & & & $\underline{\mathrm{M}}$ & & \\
\hline$\overline{\text { Negative }}$ & 24 & $40 \%$ & $\overline{\mathrm{M}} 0$ & 44 & $78.3 \%$ \\
\hline Positive & 36 & $60 \%$ & M1 & 16 & $21.7 \%$ \\
\hline PR & & & AJCC Stage group & & \\
\hline$\overline{\text { Negative }}$ & 24 & $40 \%$ & Stage I & 9 & $15 \%$ \\
\hline Positive & 36 & $60 \%$ & Stage II & 14 & $23.3 \%$ \\
\hline HER2/neu & & & Stage III & 21 & $35 \%$ \\
\hline Negative & 35 & $58.3 \%$ & Stage IV & 16 & $26.7 \%$ \\
\hline Positive & 25 & $41.7 \%$ & & & \\
\hline Ki-67 & & & P62 & & \\
\hline Negative & 23 & $38.3 \%$ & $\overline{\text { Low }}$ & 28 & $46.7 \%$ \\
\hline Positive & 37 & $61.7 \%$ & High & 32 & $53.3 \%$ \\
\hline ER/PR & & & Beclin-1 & & \\
\hline Positive/Positive & 32 & $53.3 \%$ & low & 32 & $53.3 \%$ \\
\hline Positive/Negative & 4 & $6.7 \%$ & high & 28 & $46.7 \%$ \\
\hline Negative/Positive & 4 & $6.7 \%$ & & & \\
\hline Negative/Negative & 20 & $33.3 \%$ & & & \\
\hline \multicolumn{6}{|l|}{ Molecular type } \\
\hline Luminal A & 25 & $41.7 \%$ & & & \\
\hline Luminal B & 10 & $16.7 \%$ & & & \\
\hline HER2 amplified & 15 & $25 \%$ & & & \\
\hline Triple -ve & 10 & $16.7 \%$ & & & \\
\hline
\end{tabular}

Categorical variables were expressed as number (percentage).

Continuous variables were expressed as mean \pm SD \& median (range).

Table 2:- correlation between clinicopathological features and P62 expression in our patients

\begin{tabular}{|c|c|c|c|c|}
\hline \multirow[t]{4}{*}{ Characteristics } & \multirow[t]{2}{*}{ All } & \multicolumn{2}{|c|}{ P62 } & \multirow[t]{4}{*}{ p-value } \\
\hline & & \multirow{3}{*}{$\begin{array}{c}\begin{array}{c}\text { Low } \\
(\mathrm{N}=28)\end{array} \\
\text { No. }(\%)\end{array}$} & \multirow{3}{*}{$\begin{array}{c}\begin{array}{c}\text { High } \\
(\mathrm{N}=32)\end{array} \\
\text { No. }(\%)\end{array}$} & \\
\hline & $(\mathrm{N}=60)$ & & & \\
\hline & No. $(\%)$ & & & \\
\hline \multicolumn{5}{|l|}{ Age (years) } \\
\hline Mean \pm SD & $56.35+10.99$ & $51.60 \pm 9.01$ & $60.50 \pm 11.01$ & \multirow[t]{2}{*}{0.002} \\
\hline Median (Range) & $57(39-87)$ & $50(40-76)$ & $60(39-87)$ & \\
\hline$\leq 55$ years & $24(40 \%)$ & $18(75 \%)$ & $6(25 \%)$ & $0.004 t$ \\
\hline
\end{tabular}




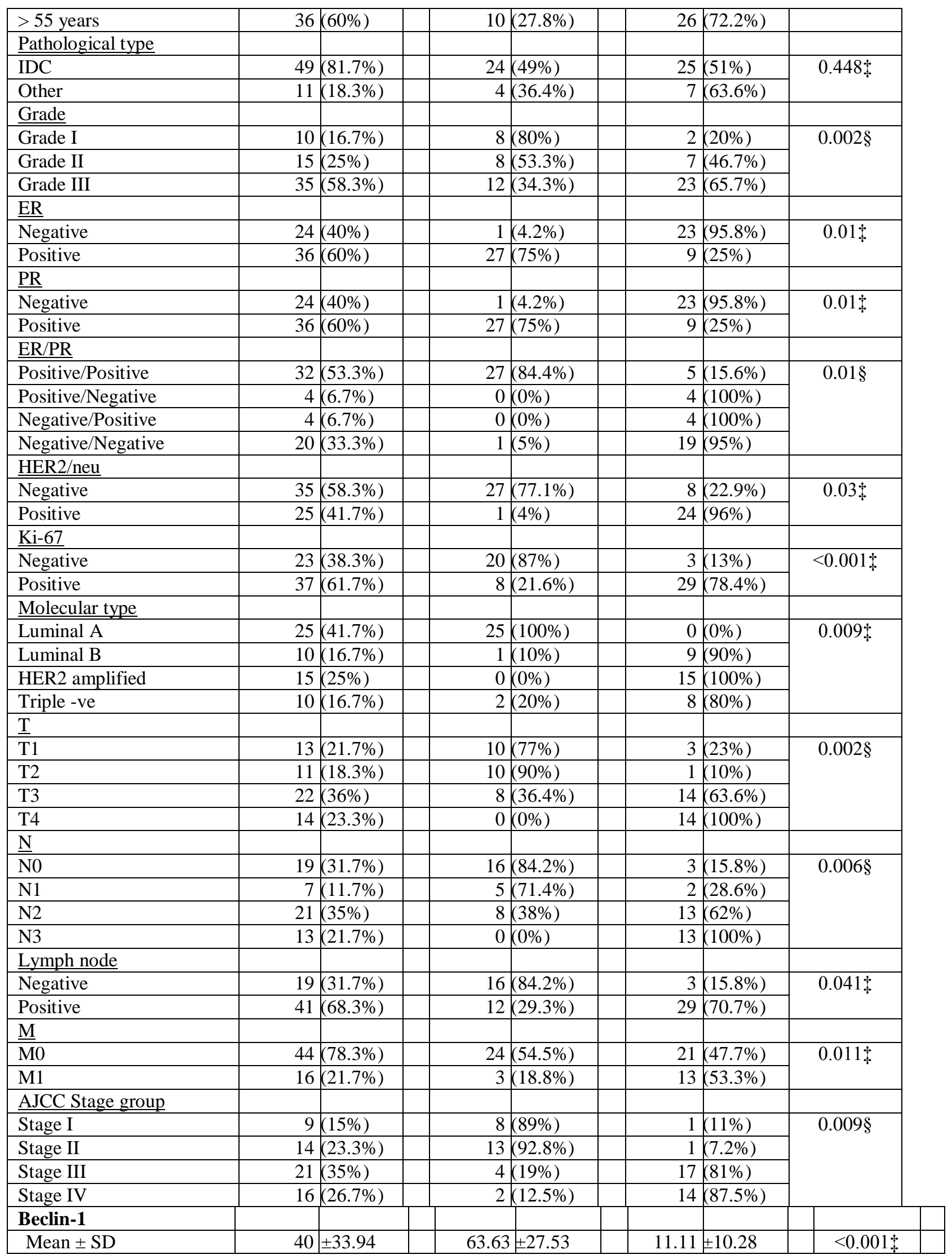




\begin{tabular}{|l|l|l|r|r|r|r|r|}
\hline Median (Range) & $25(0-90)$ & $80(0-90)$ & $12(0-25)$ & & \\
\hline Low & $32(53.3 \%)$ & $5(15.2 \%)$ & $27(100 \%)$ & $<0.001 \S$ & \\
\hline High & $28(46.7 \%)$ & $28(84.8 \%)$ & $0(0 \%)$ & $($ HS $)$ & \\
\hline
\end{tabular}

Categorical variables were expressed as number (percentage), continuous variables were expressed as mean \pm SD \& median (range);

Mann Whitney U test; $\$$ Chi-square test; $\S$ Chi-square test for trend; $p<0.05$ is significant.

Table 3:- correlation between clinicopathological features and Beclin-1 expression in our patients

\begin{tabular}{|c|c|c|c|c|c|c|}
\hline \multirow[t]{4}{*}{ Characteristics } & \multirow{2}{*}{\multicolumn{2}{|c|}{ All }} & \multicolumn{3}{|c|}{ Beclin-1 } & \multirow[t]{4}{*}{ p-value } \\
\hline & & & \multirow{2}{*}{$\begin{array}{c}\text { Low } \\
(\mathrm{N}=32)\end{array}$} & \multirow{2}{*}{\multicolumn{2}{|c|}{$\begin{array}{c}\text { High } \\
(\mathrm{N}=28)\end{array}$}} & \\
\hline & \multicolumn{2}{|c|}{$(\mathrm{N}=60)$} & & & & \\
\hline & No. & $(\%)$ & No. $(\%)$ & \multicolumn{2}{|c|}{ No. $(\%)$} & \\
\hline \multicolumn{7}{|l|}{ Age (years) } \\
\hline Mean \pm SD & 56.35 & \pm 10.99 & $60.50 \pm 11.01$ & \multicolumn{2}{|c|}{$51.60+9.01$} & \multirow[t]{2}{*}{0.004} \\
\hline Median (Range) & 57 & $(39-87)$ & $60(39.87)$ & 50 & $(40-76)$ & \\
\hline$\leq 55$ years & 24 & $(40 \%)$ & $6(25 \%)$ & 18 & $(75 \%)$ & \multirow[t]{2}{*}{$0.005 \$$} \\
\hline$>55$ years & 36 & $(60 \%)$ & $26(72.2 \%)$ & 10 & $(27.8 \%)$ & \\
\hline \multicolumn{7}{|l|}{ Pathological type } \\
\hline IDC & 49 & $(81.7 \%)$ & \multirow{2}{*}{$\begin{array}{r}25(51 \%) \\
7(63.6 \%)\end{array}$} & 24 & $(49 \%)$ & \multirow[t]{2}{*}{$0.448 \$$} \\
\hline Other & 11 & $(18.3 \%)$ & & 4 & $(36.4 \%)$ & \\
\hline \multicolumn{7}{|l|}{ Grade } \\
\hline Grade I & 10 & $(16.7 \%)$ & $3(25 \%)$ & 9 & $(75 \%)$ & \multirow[t]{3}{*}{$<0.001 \S$} \\
\hline Grade II & 15 & $(25 \%)$ & $4(23.5 \%)$ & 13 & $(76.5 \%)$ & \\
\hline Grade III & 35 & $(58.3 \%)$ & $14(77.8 \%)$ & 4 & $(22.2 \%)$ & \\
\hline \multicolumn{7}{|l|}{ ER } \\
\hline Negative & 24 & $(40 \%)$ & $23(95.8 \%)$ & 1 & $(4.2 \%)$ & \multirow[t]{2}{*}{$0.003 \$$} \\
\hline Positive & 36 & $(60 \%)$ & $9(25 \%)$ & 27 & $(75 \%)$ & \\
\hline $\mathrm{PR}$ & & & & & & \\
\hline Negative & 24 & $(40 \%)$ & $23(95.8 \%)$ & 1 & $(4.2 \%)$ & $0.003 \ddagger$ \\
\hline Positive & 36 & $(60 \%)$ & $9(25 \%)$ & 27 & $(75 \%)$ & \\
\hline ER/PR & & & & & & \\
\hline Positive/Positive & 32 & $(53.3 \%)$ & $5(15.6 \%)$ & 27 & $(84.4 \%)$ & $0.002 \S$ \\
\hline Positive/Negative & 4 & $(6.7 \%)$ & $4(100 \%)$ & 0 & $(0 \%)$ & \\
\hline Negative/Positive & 4 & $(6.7 \%)$ & $4(100 \%)$ & 0 & $(0 \%)$ & \\
\hline Negative/Negative & 20 & $(33.3 \%)$ & $19(95 \%)$ & 1 & $(5 \%)$ & \\
\hline HER2/neu & & & & & & \\
\hline Negative & 35 & $(58.3 \%)$ & $8(22.9 \%)$ & 27 & $(77.1 \%)$ & $0.006 \%$ \\
\hline Positive & 25 & $(41.7 \%)$ & $24(96 \%)$ & 1 & $(4 \%)$ & \\
\hline Ki-67 & & & & & & \\
\hline Negative & 23 & $(38.3 \%)$ & $3(13 \%)$ & 20 & $(87 \%)$ & $<0.001 t$ \\
\hline Positive & 37 & $(61.7 \%)$ & $29(78.4 \%)$ & 8 & $(21.6 \%)$ & \\
\hline Molecular type & & & & & & \\
\hline Luminal A & 25 & $(41.7 \%)$ & $0(0 \%)$ & 25 & $(100 \%)$ & $0.004 \%$ \\
\hline Luminal B & 10 & $(16.7 \%)$ & $9(90 \%)$ & 1 & $(10 \%)$ & \\
\hline HER2 amplified & 15 & $(25 \%)$ & $15(100 \%)$ & 0 & $(0 \%)$ & \\
\hline Triple -ve & 10 & $(16.7 \%)$ & $8(80 \%)$ & 2 & $(20 \%)$ & \\
\hline $\bar{T}$ & & & & & & \\
\hline $\mathrm{T} 1$ & 13 & $(21.7 \%)$ & $6(40 \%)$ & 9 & $(60 \%)$ & $0.002 \S$ \\
\hline $\mathrm{T} 2$ & 11 & $(18.3 \%)$ & $8(34.8 \%)$ & 15 & $(65.2 \%)$ & \\
\hline T3 & 22 & $(36 \%)$ & $11(73.3 \%)$ & 4 & $(26.7 \%)$ & \\
\hline $\mathrm{T} 4$ & 14 & $(23.3 \%)$ & $7(100 \%)$ & 0 & $(0 \%)$ & \\
\hline $\mathrm{N}$ & & & & & & \\
\hline N0 & 19 & $(31.7 \%)$ & $3(15.8 \%)$ & 16 & $(84.2 \%)$ & $<0.001 \S$ \\
\hline N1 & 7 & $(11.7 \%)$ & $5(45.5 \%)$ & 6 & $(54.5 \%)$ & \\
\hline
\end{tabular}




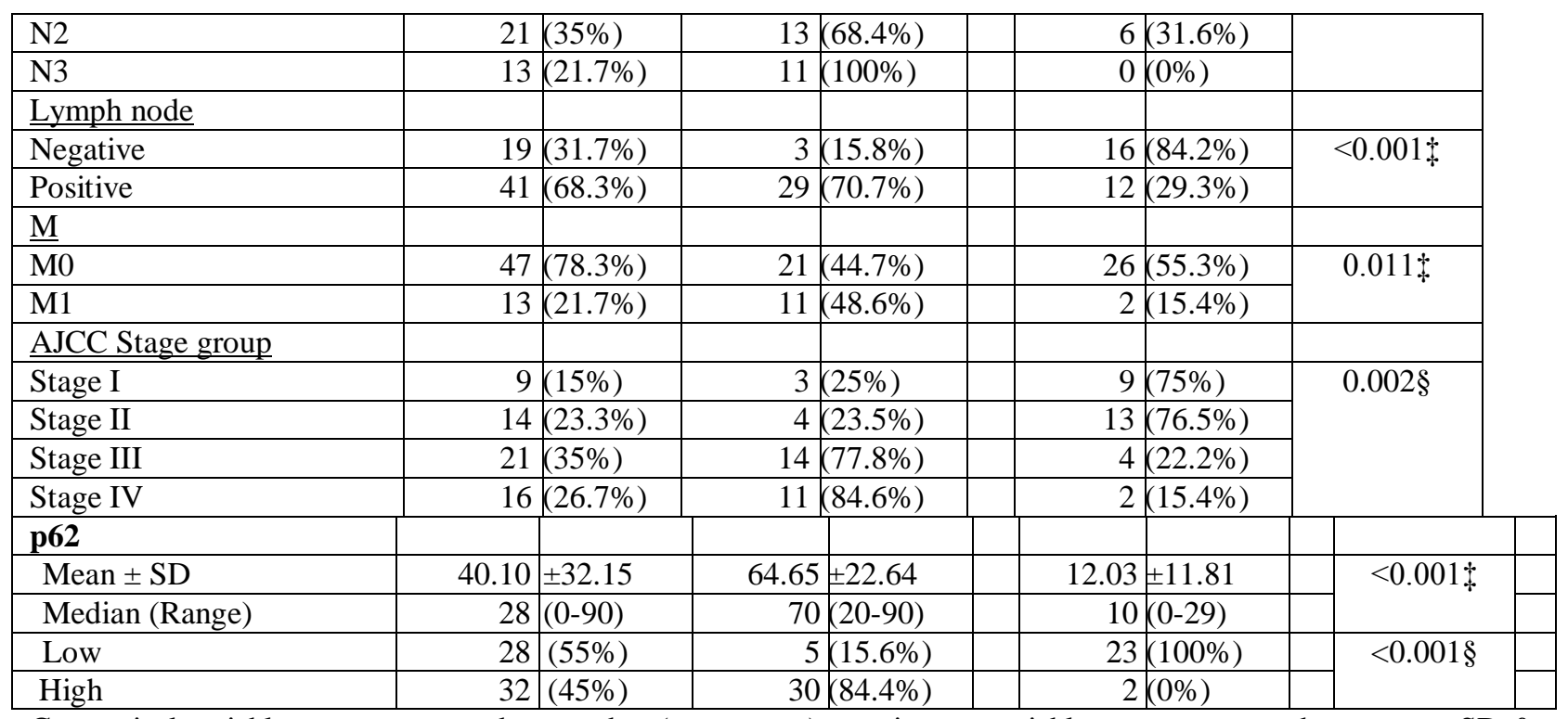

Categorical variables were expressed as number (percentage), continuous variables were expressed as mean \pm SD \& median (range); - Mann Whitney U test; $\$$ Chi-square test; $\S$ Chi-square test for trend; $p<0.05$ is significant.

Table (4): Association \& correleation between p62, Beclin-1 and clinicopathological parameters in our patients

\begin{tabular}{|l|c|c|c|c|c|c|c|c|}
\hline \multirow{2}{*}{ Age (years) } & \multicolumn{2}{c|}{$\mathbf{p 6 2}$} & \multicolumn{2}{c|}{ p62 (\%) } & \multicolumn{2}{c|}{ Beclin-1 } & \multicolumn{2}{c|}{ Beclin-1 (\%) } \\
\cline { 2 - 9 } & r & p-value & r & p-value & r & p-value & r & p-value \\
\hline Size & +0.713 & 0.009 & +0.726 & 0.008 & -0.499 & 0.04 & -0.700 & 0.03 \\
\hline Grade & +0.770 & 0.005 & +0.747 & 0.002 & -0.654 & 0.03 & -0.741 & 0.02 \\
\hline T & +0.750 & 0.01 & +0.728 & 0.02 & -0.528 & 0.02 & -0.674 & 0.03 \\
\hline N & +0.860 & 0.003 & +0.795 & 0.004 & -0.732 & 0.004 & -0.806 & 0.005 \\
\hline Stage & +0.843 & 0.002 & +0.833 & 0.003 & -0.916 & 0.005 & -0.861 & 0.005 \\
\hline p62 & +0.868 & 0.002 & +0.862 & 0.003 & -0.907 & 0.006 & -0.867 & 0.004 \\
\hline p62 (\%) & --- & --- & --- & --- & -0.846 & 0.001 & -0.759 & 0.001 \\
\hline Beclin-1 & --- & --- & --- & --- & -0.787 & 0.001 & -0.806 & 0.001 \\
\hline Beclin-1 (\%) & -0.846 & $<0.001$ & -0.787 & $<0.001$ & --- & --- & --- & --- \\
\hline
\end{tabular}

$r$ correleation coefficient; $\mathrm{p}<0.05$ is significant.

Table 5:- Diagnostic performance of immunohistochemical markers as a predictor for advanced stage breast carcinoma.

\begin{tabular}{|c|c|c|c|c|c|c|c|c|c|}
\hline Markers & $\begin{array}{c}\text { TP } \\
\text { No }(\%)\end{array}$ & $\begin{array}{c}\text { FP } \\
\text { No }(\%)\end{array}$ & $\begin{array}{c}\text { TN } \\
\text { No }(\%)\end{array}$ & $\begin{array}{c}\text { FN } \\
\text { No }(\%)\end{array}$ & $\begin{array}{c}\mathrm{SN} \% \\
(95 \% \mathrm{CI})\end{array}$ & $\begin{array}{c}\mathrm{SP} \% \\
(95 \% \mathrm{CI})\end{array}$ & $\begin{array}{c}\text { PPV \% } \\
(95 \% \mathrm{CI})\end{array}$ & $\begin{array}{c}\text { NPV \% } \\
(95 \% \text { CI })\end{array}$ & $\begin{array}{l}\text { Accuracy } \\
(95 \% \text { CI })\end{array}$ \\
\hline P62 ( & $32(45 \%)$ & $0(0 \%)$ & $\begin{array}{c}23 \\
(38.3 \%)\end{array}$ & $9(16.7 \%)$ & $\begin{array}{c}72.4 \% \\
(58.2-86.6)\end{array}$ & $\begin{array}{c}97.9 \% \\
(92.2-100)\end{array}$ & $\begin{array}{c}98.2 \% \\
(93.3-100)\end{array}$ & $\begin{array}{c}69.1 \% \\
(53.6-84.6)\end{array}$ & $\begin{array}{c}82.2 \% \\
(72.6-91.7)\end{array}$ \\
\hline $\begin{array}{l}\text { Beclin-1 } \\
\text { (Low) }\end{array}$ & $\begin{array}{c}32 \\
(53.3 \%)\end{array}$ & 0 & $\begin{array}{c}23 \\
(38.3 \%)\end{array}$ & $\%)$ & $\begin{array}{c}85.5 \% \\
(74.3-96.7)\end{array}$ & $\begin{array}{c}97.9 \% \\
(92.2-100)\end{array}$ & $\begin{array}{c}98.5 \% \\
(94.3-100)\end{array}$ & $\begin{array}{c}81 \% \\
(66.8-95.3)\end{array}$ & $\begin{array}{c}90.3 \% \\
(82.9-97.6)\end{array}$ \\
\hline
\end{tabular}

TP: True positive; FP: False positive; TN: True negative; FN: False negative; SN: Sensitivity; SP: Specificity; PPV: Positive Predictive Value; NPV: Negative Predictive Value, 95\%CI: 95\% Confidence Interval; $\mathrm{p}<0.05$ is significant.

\section{Discussion:-}

Clinicopathological role of autophagy in cancer is still a point of research that could be due to variability in its role in carcinogenesis (White, 2012). In this study, we found that SQSTM1-p62 overexpression was correlated positively with a poor clinical behavior of cancer such as large size, higher incidence of positive lymph nodes, higher grade, and advanced stage and high incidence of distant metastases occurrence in patients with breast carcinoma $(\mathrm{P}<0.001)$. 
Chen et al., 2013; Luo et al., 2013, proved similar findings to us that SQSTM1-p62 over expression in carcinoma of the breast was related to bad clinicopathological criteria, on the contrary Jiang et al. (2012) proved different findings to us. Sakakura et al. (2015) explained such conflicting results to differences in evaluation of positive areas in carcinoma tissues in between the peripheral and the central area, that were different in composition, while most researches had not analyze which positive part that they have found in cancer tissue. Many conflicting results had been discovered regarding clinicopathological role of Beclin-1, that is important the autophagy-related protein, expression in breast carcinoma. We declared that Beclin-1 expression in breast carcinoma was strongly negatively correlated to size, grade and stage of the tumor, the presence of nodal and/or distant metastasis. Beclin-1 overexpression was strongly positively correlated with good clinicopathological criteria in breast carcinoma. Dong et al., 2013 proved similar to our results that elevated Beclin-1 expression in carcinoma of the breast was an indicator of good clincopathological criteria. On the contrary, He et al. 2014 meta-analysis results and Choi et al., 2014 results have detected no characteristic relation between overexpression of Beclin-1 and clinicopathological parameters of breast carcinoma. Moreover, Won et al., 2009, had declared no relation was found between expression of Beclin-1 and prognosis of breast cancer patients. Ahn et al. 2007 explained the absence of such a relation between the expression of Beclin- 1 and clinic-pathological characteristics that Beclin-1 could be able to play a role in malignant initiation but had no role in carcinoma progression. Similar tour results in breast cancer Qiu et al. (2014, had found that over expression of Beclin-1 in liver carcinoma was strongly related to good prognosis. He et al. 2014 meta-analysis had showed that Beclin-1 increased expression could be able to be a protective factor in stomach cancer and lymphoma that was similar to our results in cancer breast, but it had no clinicopathological relation to colon or lung cancers. On the contrary to our results, Han et al. 2014 had found that Beclin-1 over expression in cancer colon was associated with increased incidence of L.N, blood metastasis and associated with poor prognosis. So it had been found that both Beclin-1 increased or decreased expression were detected in human malignancies; as it may had a cancer suppressor role, by interacting with bcl-2 protein members (Cao and Klionsky, 2007). Otherwise the tumor stimulatory role of Beclin-1 overexpression in which it was associated with cancers aggressive behavior was done by anti-apoptotic machinery potentiation (Koukourakis et al. 2010), and another mechanism Beclin-1 overexpression during adverse cancer environmental conditions like hypoxia and increased acidity, so as to allow cancer cells to overcome such conditions by increasing autophagic cancer cells activity to recycle un needed proteins and damaged organelles to increased their survival (Samokhvalov et al., 2008). However Beclin-1 over expression could be able to delay cancer progression by decreasing chromosomal instability and the occurrence of more mutation (Mathew et al., 2007). That may be due to Beclin-1-dependent autophagy which induced immunological response (Xu et al., 2008).

In summary, in our study we proved that SQSTM1/p62 expressions were strongly positively related to bad clinicopathological parameters of cancer breast patients and its expression was negatively correlated to Beclin-1 expression, which was proved to be a marker of favorable prognosis for cancer breast patients. There are conflicting results on the prognostic value of both markers in cancer breast. We recommended to do more studies confirm their role as clinical predictors of poor or good clinicopathological criteria and different outcome for breast cancer patients that may help to detect novel therapeutic targets to for them improving their prognosis.

\section{Conclusion:-}

SQSTM1/p62 is markers of a poor prognosis, while Beclin-1 is a marker of a good prognosis in in breast cancer.

\section{Conflicts of interest}

None declared.

\section{References:-}

1. Siegel R, Ma J, Zou Z, Jemal A (2014). Cancer statistics. CA: A Cancer J Clin 64:9-29.

2. Mokhtar N, Gouda I and Adel I (2007); - pathology registry 2003-2004 Department of pathology, NCI.

3. Jemal A, Center MM, DeSantis C, Ward EM (2010). Global patterns of cancer incidence and mortality rates and trends. Cancer Epidemiol Biomarkers Prev 19:1893-1907.

4. Young AR, Narita M, Ferreira M, Kirschner K, Sadaie M, Darot JF, et al (2009). Autophagy mediates the mitotic senescence transition. Genes Dev 23: 798-803.

5. Mathew R, White E (2011). Autophagy in tumorigenesis and energy metabolism: friend by day, foe by night. Curr Opin Genet Dev 21:113-119. 
6. White E (2012). Deconvoluting the context-dependent role for autophagy in cancer. Nat Rev Cancer 12:401410.

7. Weidberg H, Shvets E, Elazar Z (2011). Biogenesis and cargo selectivity of autophagosomes. Annu Rev Biochem 80:125-156.

8. Cao Y, Klionsky DJ (2007). Physiological functions of Atg6/Beclin 1: a unique autophagy-related protein. Cell Res 17:839-849.

9. Kondo Y, Kanzawa T, Sawaya R, Kondo S (2005). The role of autophagy in cancer development and response to therapy. Nat Rev Cancer 5:726-734.

10. Lamark T, Kirkin V, Dikic I, Johansen T (2009). NBR1 and p62 as cargo receptors for selective autophagy of ubiquitinated targets. Cell Cycle 8:1986-1990.

11. Edge SB, Compton CC (2010). The American Joint Committee on Cancer: the 7th edition of the AJCC cancer staging manual and the future of TNM. Ann Surg Oncol 17:1471-1474.

12. Elston CW (2002). Pathological prognostic factors in breast cancer I. The value of histological grade in breast cancer: experience from a large study with long-term follow-up. Histopathology 19:403-410.

13. Hsu SM, Raine L, Fanger H (1981). Use of avidin-biotin-peroxidase complex (ABC) in immunoperoxidase techniques: a comparison between $\mathrm{ABC}$ and unlabeled antibody (PAP) procedures. J Histochem Cytochem 29:577-580.

14. Won KY, Kim GY, Kim YW, Song JY, Lim SJ (2010). Clinicopathologic correlation of beclin-1 and bcl-2 expression in human breast cancer. Hum Pathol 41:107-112.

15. Chen Y, Li X, Wu X, He C, Guo L, Zhang S, et al (2013). Autophagy-related proteins LC3 and Beclin-1 impact the efficacy of chemoradiation on esophageal squamous cell carcinoma. Pathol Res Pract 209:562-567.

16. Luo RZ, Yuan ZY, Li M, Xi SY, Fu J, He J (2013). Accumulation of p62 is associated with poor prognosis in patients with triple-negative breast cancer. Onco Targets Ther 6:883-888.

17. Jiang L, Huang S, Li W, Zhang D, Zhang S, Zhang W, et al (2012). Expression of autophagy and ER stressrelated proteins in primary salivary adenoid cystic carcinoma. Pathol Res Pract 208:635-641.

18. Sakakura K, Takahashi H, Kaira K, Toyoda M, Oyama T, Chikamatsu K (2015). Immunological significance of the accumulation of autophagy components in oral squamous cell carcinoma. Cancer Sci 106:1-8.

19. Dong M,Wan XB, Yuan ZY,Wei L, Fan XJ,Wang TT, et al (2013). Low expression of Beclin 1 and elevated expression of HIF-1a refine distant metastasis risk and predict poor prognosis of ER-positive, HER2-negative breast cancer. Med Oncol 30:355.

20. He Y, Zhao X, Subahan NR, Fan L, Gao J, Chen H (2014). The prognostic value of autophagy-related markers beclin-1 and microtubule-associated protein light chain 3B in cancers: a systematic review and meta-analysis. Tumour Biol 35:7317-7326.

21. Ahn CH, Jeong EG, Lee JW, Kim MS, Kim SH, Kim SS, et al (2007). Expression of beclin-1, an autophagyrelated protein, in gastric and colorectal cancers. APMIS 115:pp. 1344-1349.

22. Qiu DM,Wang GL, Chen L, Xu YY, He S, Cao XL, et al (2014). The expression of beclin-1, an autophagic gene, in hepatocellular carcinoma associated with clinical pathological and prognostic significance. BMC Cancer 14:327.

23. Han Y, Xue XF, Shen HG, Guo XB, Wang X, Yuan B, et al (2014). Prognostic significance of Beclin-1 expression in colorectal cancer: a meta-analysis. Asian Pac J Cancer Prev 15:4583-4587.

24. Koukourakis MI, Giatromanolaki A, Sivridis E, Pitiakoudis M, Gatter KC, Harris AL (2010). Beclin 1 overand under-expression in colorectal cancer: distinct patterns relate to prognosis and tumor hypoxia. $\mathrm{Br} \mathrm{J}$ Cancer 103:1209-1214.

25. Samokhvalov V, Scott BA, Crowder CM (2008). Autophagy protects against hypoxic injury in C. elegans. Autophagy 4:1034-1041.

26. Mathew R, Kongara S, Beaudoin B, Karp CM, Bray K, Degenhardt K, et al (2007). Autophagy suppresses tumor progression by limiting chromosomal instability. Genes Dev 21:1367-1381.

27. Xu Y, Liu XD, Gong X, Eissa NT (2008). Signaling pathway of autophagy associated with innate immunity. Autophagy 4:110-112. 